\title{
A Videofluoroscopic Study of the Emphatic Consonants in Jordanian Arabic
}

\author{
Feda Al-Tamimi ${ }^{a}$ Firas Alzoubi ${ }^{b}$ Rama Tarawnah ${ }^{c}$ \\ ${ }^{a}$ Department of English/Department of Allied Health Sciences and ${ }^{b}$ Department of Special Surgery, \\ Jordan University of Science and Technology, Irbid, and ' AI-Balqa Applied University, Al-Salt, Jordan
}

\section{Key Words}

Videofluoroscopic study · Arabic emphatics · Articulatory phonetics

\begin{abstract}
In order to identify the nature of the emphatic consonants and the articulatory features accompanying their production, 384 videofluoroscopic images of 2 male and 2 female Jordanian speakers were analyzed. Analysis focused on the differences between nonemphatic and emphatic consonants in the pharyngeal length and width, the hyoid bone elevation and larynx raising. Results show that males and females produce emphatics as pharyngealized sounds with the tongue root retracting into the oropharynx and the hyoid bone elevating and the larynx raising as a result.
\end{abstract}

Copyright $\odot 2009$ S. Karger AG, Basel

\section{Introduction}

/təfxi:m/ or emphasis is a term meaning 'dignifying'. Medieval Arab linguists referred to emphasis with terms like / $\mathrm{Pt}^{\mathrm{S}} \mathrm{baq} /$ (lidding) and / IIstI Slaa?/ (raising). The term $/ 2 \mathrm{t}^{\mathrm{S}} \mathrm{baq} /$ includes four coronal emphatics: a voiceless dental stop $/ \mathrm{t}^{\mathrm{f}} /$, a voiced dental stop $/ \mathrm{d}^{\mathrm{f}} /$, a voiceless alveolar fricative $/ \mathrm{s}^{\mathrm{S}} /$ and a voiced interdental fricative $/{ }^{\mathcal{I}} \%$ /?Istrilaa?/ refers to these consonants and the voiceless and voiced velar fricatives $/ \mathrm{x} /$ and $/ \mathrm{y} /$ and the voiceless uvular stop /q/. $/ \mathrm{t}^{\mathrm{f}}, \mathrm{d}^{\mathrm{f}}, \mathrm{s}^{\mathrm{f}}, \mathrm{\partial}^{\mathrm{f}} /$ have primary anterior and secondary posterior places of articulation, while /x, $\mathrm{y}, \mathrm{q} /$ have primary posterior places of articulation only. Phoneticians and phonologists alternate between the terms /təfxi:m/ and /mufaxxam/; /mufaxxam/ as an adjective of the noun /təfxi:m/ is related to two distinctive features: 'tense' and 'pharyngealized'. /təfxi:m/ covers a combination of distinctive features, such as 'tense', 'long', 'flat', and 'back' [1].

From an articulatory point of view, researchers believe that emphasis is realized as either velarization or pharyngealization. Gairdner [2, p. 192] believes that emphasis is velarization 'because the most prominent feature of the phenomenon is the raising of the back of the tongue towards the soft palate'. Trubetzkoy [1] uses the term 'emphatic velarization' to refer to the back movement of the tongue. He states that ' $\ldots$ it is necessary to distinguish the correlation of emphatic velarization that plays an important role in the Semitic languages, especially Arabic. The Arabic emphatic consonants are characterized by a thickening of the root of the tongue, which at the same time causes a shift of the larynx' [1, p. 131]. O'Connor [3] adopts the same view and claims that velarization is the main feature for differentiating between emphatic and nonemphatic consonants.

On the other hand, other researchers [4-9] believe that /təfxi:m/ is realized as pharyngealization. Delattre [6, p. 129] states that emphatics are produced when 'the root of the tongue assumes the shape of a bulge and is

\section{KARGER}

Fax +4161306 1234

E-Mail karger@karger.ch

www.karger.com (c) 2009 S. Karger AG, Basel

1021-7762/09/0614-0247\$26.00/0

Accessible online at:

www.karger.com/fpl
Feda Al-Tamimi

Department of English/Department of Allied Health Sciences

Jordan University of Science and Technology

Irbid 22110 (Jordan)

E-Mailf-tamimi@just.edu.jo 
drawn back towards the vertical back wall of the pharynx to form a stricture'. Khan's [10] definition of /təfxi:m/ as a 'secondary articulation' goes in line with this approach. Davis [11] believes that these sounds are produced with a primary articulation in the dental/alveolar region and a secondary articulation in the upper pharynx.

A third view is held by Zawaydeh [12,13] suggesting that /təfxi:m/ is uvularization. She believes that uvularization as a secondary articulation is the result of tongue back retraction towards the uvula.

This disparity might be related to articulatory variations among the different Arabic dialects [14] and the impressionistic view that some researchers adopted in their early accounts of emphatic consonants [7]. What is of special importance for us in this study is Zawaydeh's $[12,13]$ belief that /təfxi:m/ is uvularization. The subject of Zawaydeh's two studies is the author herself. A fiber-optic endoscope was inserted through her nasal passage into the pharynx an inch below the uvula. A list of emphatic, uvular, pharyngeal and laryngeal sounds were videotaped. As a result of the endoscopic images and the acoustic analysis, Zawaydeh believes that emphatics in Arabic are uvularized.

\section{The Articulatory Mechanism of the Emphatics}

Odisho [15, p. 37] believes that /təfxi:m/ is achieved in everyday speech through 'a complex of articulatory movements leading to a rapidly shifting and complicated configuration of the vocal tract beginning from a slightly raised larynx and ending with slightly rounded and protruded shape of the lips'. Panconcelli-Calzia [16] suggests that /təfxi:m/ is characterized by a contraction of the pharyngeal muscles with the hyoid bone being retracted and the larynx raised. This is accompanied by lowering the epiglottis towards the glottis. The difference between Panconcelli-Calzia [16] and Marçais [17] is that for Panconcelli-Calzia it is the contraction of the pharynx and the retraction of the hyoid bone that causes the constriction, while for Marçais it is the retraction of the root of the tongue into the pharynx that causes this constriction.

Ali and Daniloff [8] agree that it is the tongue root retraction into the pharynx that causes the constriction without a noticeable raising of the hyoid bone or the larynx. Al-Ani [5] adds to this laryngeal constriction a slight retraction of the tongue from its main place of articulation. In their fiber-optic study, Laufer and Baer [7, p. 193] find that during the production of emphatic sounds 'the epiglottis forms a constriction with the pharyngeal walls and that the root of the tongue, at the bottom of the pharynx, also moves backward'. Those who believe that /təfxi:m/ is velarization agree with most of these articulatory postures and stress the fact that the 'back of the tongue is raised towards the back of the velum' [2, p. 21].

To sum up, the common physiological configurations for the production of emphasis based on the previously discussed studies incorporate a retraction of the tongue back/root towards the uvula/velum or posterior pharynx and with a slight retraction of the tongue tip within the place of primary articulation of the sound. This is accompanied by a lateral pharyngeal constriction and a slight raising of the epiglottis and larynx. Slight lip rounding and protrusion have also been noted [18]. The disparity regarding the zone of tongue retraction, i.e. velum [1-3], posterior pharynx [4-11], or uvula [12,13], is accompanied by different views concerning whether hyoid bone and larynx settings are secondary dependent $[8,17]$ or independent [16] consequences of tongue gesture.

\section{Method}

The aim of the study is to identify the articulatory mechanisms involved in the production of Jordanian emphatic consonants. To achieve this goal, 2 males and 2 females with graduate degrees in the Arabic language and literature participated in the current study. They were in their mid twenties to mid thirties with Jordanian Arabic being their first language. They all signed a consent form informing them of the materials (i.e. barium) and ionizing radiation used in the videofluoroscopic sessions. Participants sat for a tape-recorded interview with 2 trained speech therapists who asked them to read the study word list (table 1). The everyday lect of 1 of the 2 males and females was the Jordanian colloquial spoken urban variety, while the other male and female speakers used the Jordanian colloquial spoken rural variety. Choosing participants specialized in Arabic made it easy for them to produce any of the study words. At the same time, their knowledge and usage of the colloquial spoken Jordanian varieties made them able to produce some of the study words with their different phonetic realizations. The speech of the participants seemed normal to the 3 authors of the study. They pronounced the target sounds in a very natural way. They neither sounded overly formal nor deeply colloquial.

The recording sessions started with the speakers reading each of the words in the list twice. They all started with the standard pronunciation for $/ t^{\uparrow}, d^{\uparrow}, s^{\uparrow} /$. The speakers coming from urban dialectal backgrounds were then asked to read the etymological $/ \mathrm{d}^{\mathrm{f}} /$ words as $\left[\mathrm{d}^{\mathrm{f}}\right]$ and the speakers coming from rural dialectal backgrounds were then asked to read these etymological $/ \mathrm{d}^{\mathrm{f}} /$

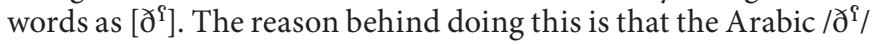
words are limited in number. Moreover, it is extremely difficult to find $/ \mathrm{d}^{\mathrm{q}} /$ and $/ \gamma^{\mathrm{f}} /$ minimal or minimal-like pairs. The $/ \mathrm{d}^{\mathrm{q}} /$ words used in the study were all familiar to the speakers and com- 
Table 1. Study word list

\begin{tabular}{|c|c|c|c|c|}
\hline Plain/emphatic & Plains & Meaning & Emphatics & Meaning \\
\hline /t- vs. $\mathrm{t}^{\mathrm{f}} /$ & $\begin{array}{l}\text { /tædz/ } \\
\text { /ti:n/ } \\
\text { /tu:b/ }\end{array}$ & $\begin{array}{l}\text { crown } \\
\text { figs } \\
\text { repent }\end{array}$ & $\begin{array}{l}/ \mathbf{t}^{\mathrm{f}} \mathrm{ab} / \\
/ \mathbf{t}^{\mathrm{f}} \dot{\mathrm{t}} \mathrm{n} / \\
/ \mathbf{t}^{\mathrm{f}} \mathrm{u}: \mathrm{b} /\end{array}$ & $\begin{array}{l}\text { recovered } \\
\text { mud } \\
\text { bricks }\end{array}$ \\
\hline /-t vs. $-\mathrm{t}^{\mathrm{f}} /$ & $\begin{array}{l}\text { /bæt/ } \\
\text { /takr i:t/ } \\
\text { /fu:t/ }\end{array}$ & $\begin{array}{l}\text { stayed } \\
\text { a city in Iraq } \\
\text { enter }\end{array}$ & $\begin{array}{l}/ \text { bat }^{\mathrm{i}} / \\
/ \int \operatorname{ari}^{\mathrm{i}} \mathrm{t}^{\mathrm{i}} / \\
/ \mathrm{bu}: \mathrm{t}^{\mathrm{i}} /\end{array}$ & $\begin{array}{l}\text { armpit } \\
\text { ribbon } \\
\text { sport shoes }\end{array}$ \\
\hline /d- vs. d ${ }^{\mathrm{f}}-/$ & $\begin{array}{l}\text { /dær/ } \\
\text { /radi:f/ } \\
\text { /du:dz/ }\end{array}$ & $\begin{array}{l}\text { house } \\
\text { one following next in line } \\
\text { tour villages riding donkeys }\end{array}$ & $\begin{array}{l}/ \mathbf{d}^{\mathrm{i}} \mathrm{ar} / \\
/ \mathbf{d}^{\mathrm{i}} \mathbf{i}: \mathrm{f} / \\
/ \mathbf{d}^{\mathrm{i}} \mathrm{u}: \mathrm{d} z /\end{array}$ & $\begin{array}{l}\text { harmful } \\
\text { add } \\
\text { get annoyed }\end{array}$ \\
\hline /-d vs. - $\mathrm{d}^{\mathrm{i}} /$ & $\begin{array}{l}\text { /bæd/ } \\
\text { /bi:d/ } \\
\text { /furu:d/ }\end{array}$ & $\begin{array}{l}\text { vanished } \\
\text { scatter } \\
\text { guns }\end{array}$ & $\begin{array}{l}\text { /bad }{ }^{\mathrm{f}} / \\
\text { /bi:d } \\
\text { /furt: } \\
\text { / }\end{array}$ & $\begin{array}{l}\text { laid eggs } \\
\text { white } \\
\text { duties }\end{array}$ \\
\hline /s- vs. $s^{i}-/$ & $\begin{array}{l}\text { /sæb/ } \\
\text { /si:b/ } \\
\text { /suus/ }\end{array}$ & $\begin{array}{l}\text { let go (past) } \\
\text { let go (imp.) } \\
\text { mothworm }\end{array}$ & $\begin{array}{l}/ s^{i} a b / \\
/ s^{i} \dot{i}: b / \\
/ s^{i} u: s^{i} /\end{array}$ & $\begin{array}{l}\text { hit } \\
\text { hit (imp.) } \\
\text { young chicken }\end{array}$ \\
\hline /-s vs. $-s^{q} /$ & $\begin{array}{l}\text { /bæs/ } \\
\text { /si:s/ } \\
\text { /su:s/ }\end{array}$ & $\begin{array}{l}\text { kissed } \\
\text { lead (imp.) } \\
\text { mothworm }\end{array}$ & 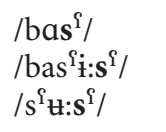 & $\begin{array}{l}\text { bus } \\
\text { glow } \\
\text { young chicken }\end{array}$ \\
\hline /ð- vs. $ð^{\S}-/$ & $\begin{array}{l}\text { /ðæb/ } \\
\text { /ði:b/ } \\
\text { /ðu:b/ }\end{array}$ & $\begin{array}{l}\text { melted } \\
\text { wolf } \\
\text { melt }\end{array}$ & 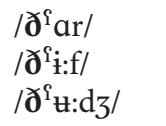 & $\begin{array}{l}\text { harmful } \\
\text { add } \\
\text { get annoyed }\end{array}$ \\
\hline /-ð vs. - ð؟/ & $\begin{array}{l}\text { /raðæð/ } \\
\text { /nabi:ð/ } \\
\text { /nufu:ð/ }\end{array}$ & $\begin{array}{l}\text { drizzle } \\
\text { wine } \\
\text { power }\end{array}$ & 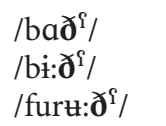 & $\begin{array}{l}\text { laid eggs } \\
\text { white } \\
\text { duties }\end{array}$ \\
\hline
\end{tabular}

mon in their everyday rural dialect. So, it was thought that using the same words of the list with $/ \mathrm{d}^{\mathrm{\Upsilon}} /$ and $/{ }^{\mathrm{f}} /$ interchangeably would give more credibility to the study.

Different steps were followed to achieve reliable and representative data. First, to examine the familiarity of the word list to the Jordanian community, a group of 50 quasi-randomly chosen Jordanian male and female adult undergraduate students speaking the urban and rural Jordanian dialects were divided into two judgment groups. The first group was asked to write down the meanings of the $/ \mathrm{t}^{\mathrm{i}}, \mathrm{d}^{\mathrm{i}}, \mathrm{s}^{\mathrm{i}} /$ words that were read to them loudly in standard Arabic. The second group was also asked to write down the meanings of the $/ \mathrm{d}^{\mathrm{f}} / \rightarrow\left[\check{\partial}^{\mathrm{f}}\right]$ words that were read to them in the rural Jordanian colloquial Arabic. All participants were 95\% similar to each other in the meanings they gave to all the words.

Second, measurements were done by a radiologist blind to the type of consonants produced. The total number of frames that were available at the end of the study was 384 . These were $48 \mathrm{im}$ ages for the emphatic/nonemphatic sounds produced by 4 speakers twice each. The frames of the nonemphatic sounds were given to the radiologist to measure the pharyngeal length and width, and the exact location of the larynx and hyoid bone. The results of every two frames for the same nonemphatic sound were aver- aged. The same procedure was applied to the emphatic counterparts.

The pharyngeal length $(9.5 \mathrm{~cm}$ for males and $8.5 \mathrm{~cm}$ for females) of the 4 speakers was measured based on the distance between the skull base and the larynx opposite the cervical vertebrae (B to $\mathrm{B}+$ ). The exact location of the larynx was opposite the upper margin of the 5 th cervical vertebra for males and the lower margin of the 4 th cervical vertebra for females (A to A+). The oropharyngeal width was measured based on the distance between the anterior edge of the vertebral body and the tongue root ( $\mathrm{D}$ to $\mathrm{D}+$ ). The hyoid bone was located based on a straight line leveled with its lower edge and the 3rd vertebra (C to $\mathrm{C}+$ ) (fig. 1).

The actual length and width of the pharynx, hyoid bone elevation and larynx raising for all speakers were measured after calculating the magnification factor (MF) for videofluoroscopic images. The MF was measured after dividing the focus-image distance (FID) by the focus-object distance (FOD). The FID is concerned with the distance between the focusing cup from where $\mathrm{X}$-rays originate towards the image intensifier and the FOD is concerned with the distance between the focusing cup and the object or body part. The difference was applied on a coin by measuring its real diameter and comparing it to the diameter mea- 
Fig. 1. Videofluoroscopy of /sæb/ and $/ \mathrm{s}^{\mathrm{i}} \mathrm{ab} /$ produced by a male speaker showing the corner lines of measurement.
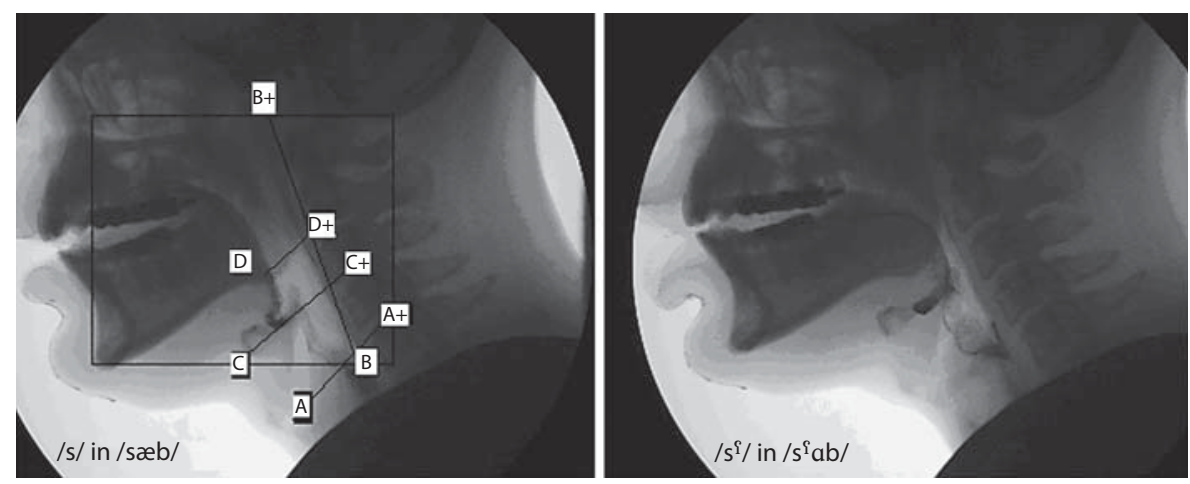

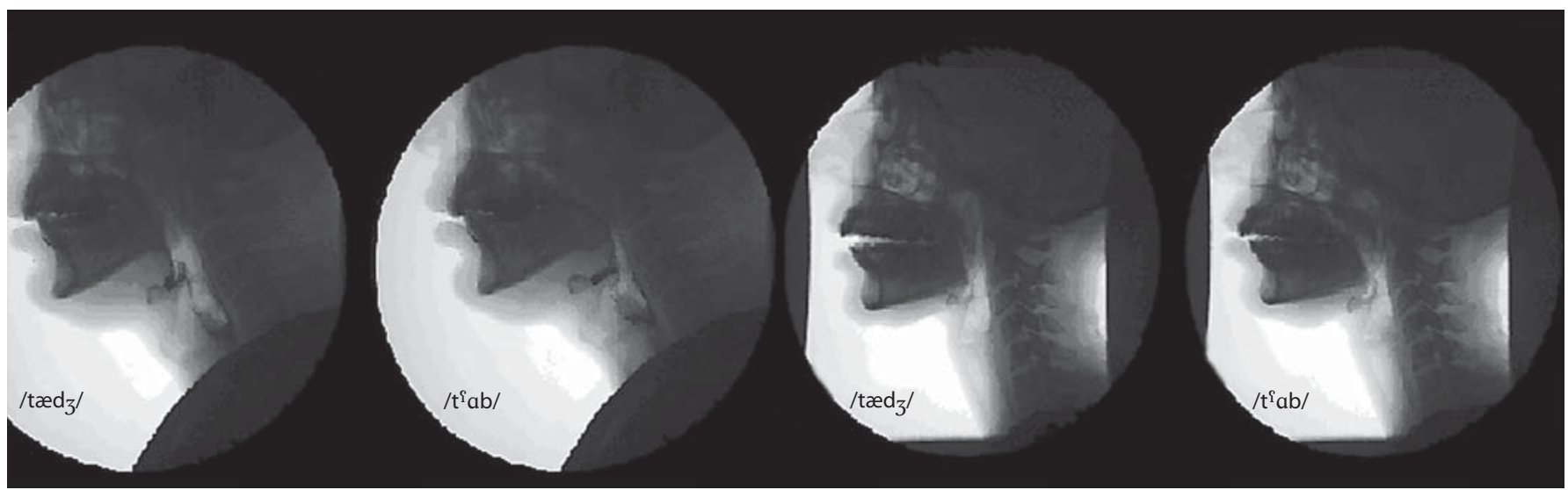

Fig. 2. /tædz/ ('crown') and / $\mathrm{t}^{\mathrm{f}} \mathrm{ab}$ / ('recovered') produced by a male speaker (the first two frames) and a female speaker (the second two frames).

sured on the frame. The MF appeared to be 1.10714. The length and width of the pharynx were measured on the videofluoroscopic image and then divided by MF to know the real size of the pharynx. For example, the pharyngeal length was almost 10.51 on the videofluoroscopic image. The real length appeared to be 9.5 for males (i.e. 10.51/1.10714).

Accordingly, the pharynx length and width, hyoid bone elevation and larynx raising from the source (i.e. 3rd vertebra and 4th/ 5 th vertebrae, respectively) were measured for emphatic consonants in comparison with their nonemphatic counterparts. The tongue, hyoid bone and larynx gestures of the nonemphatic sounds were considered as reference points in calculating the percentage of changes in the emphatic sounds.

\section{Recording Sessions}

The 4 subjects of the study were provided with thick liquid barium to swallow prior and during the recording sessions. It helped in temporarily coating the inside lining of the mouth, pharynx and larynx, allowing the outline of these organs to be visible for live imaging. The videofluoroscopy was performed with the subject in the upright position in the lateral projection using a Toshiba videofluoroscopy machine coupled with two monitors. All subjects were asked to wear aprons for safety procedures.

Four persons were present during the recording sessions: a radiologist to administer the test, the first author with a trained speech therapist to watch one of the monitors and write down the exact frame of the target sound, and the second author with another trained speech therapist to watch the other monitor and record the live images appearing on the screen and the voice of the participant using a cam-camera. The speech therapists' notes, the cam-camera film and the images saved on the videofluoroscopy machine were reviewed by the authors and the speech therapists to agree on the exact frame of every target sound.

\section{Results}

The nonemphatic/emphatic word-initial and -final sounds examined in this study were $/ \mathrm{t}, \mathrm{t}^{\mathrm{f}} /, / \mathrm{d}, \mathrm{d}^{\mathrm{f}} /, / \mathrm{s}, \mathrm{s}^{\mathrm{f}} /$ and $/ \partial$, $\chi^{\mathrm{S}} \%$ Results show that different articulatory mechanisms occur simultaneously to produce the emphatic 
Table 2. $/ \mathrm{t}^{\mathrm{f}} /$ word-initial and -final in three-vocalic contexts

\begin{tabular}{lllrrr}
\hline Emphatics & $\begin{array}{l}\text { Tongue } \\
\text { projection }\end{array}$ & $\begin{array}{l}\text { Hypoid bone } \\
\text { elevation }\end{array}$ & $\begin{array}{r}\text { Larynx } \\
\text { raising }\end{array}$ & $\begin{array}{l}\text { Oropharyngeal } \\
\text { narrowing }\end{array}$ \\
\hline$/ \mathbf{t}^{\mathrm{i}} \mathrm{ab} /$ & $\mathrm{M}$ & oropharynx & $6 \%$ & $10 \%$ & $9 \%$ \\
& $\mathrm{~F}$ & oropharynx & $4 \%$ & $7 \%$ & $3 \%$ \\
$/ \mathbf{t}^{\mathrm{i}} \mathrm{i}: \mathrm{n} /$ & $\mathrm{M}$ & oropharynx & $6 \%$ & $12 \%$ & $13 \%$ \\
& $\mathrm{~F}$ & oropharynx & $3 \%$ & $8 \%$ & $8 \%$ \\
$/ \mathbf{t}^{\mathrm{i}} \mathrm{u}: \mathrm{b} /$ & $\mathrm{M}$ & oropharynx & $10 \%$ & $15 \%$ & $11 \%$ \\
& $\mathrm{~F}$ & oropharynx & $5 \%$ & $5 \%$ & $5 \%$ \\
$/ \mathrm{bat}^{\mathrm{i}} /$ & $\mathrm{M}$ & oropharynx & $8 \%$ & $8 \%$ & $13 \%$ \\
& $\mathrm{~F}$ & oropharynx & $3 \%$ & $2 \%$ & $9 \%$ \\
$/ \mathrm{Jari}_{\mathrm{i}} \mathbf{t}^{\mathrm{f}} / \mathrm{M}$ & oropharynx & $5 \%$ & $7 \%$ & $16 \%$ \\
& $\mathrm{~F}$ & oropharynx & $3 \%$ & $4 \%$ & $5 \%$ \\
$/ \mathrm{bu}: \mathrm{t}^{\mathrm{i}} /$ & $\mathrm{M}$ & oropharynx & $10 \%$ & $10 \%$ & $11 \%$ \\
& $\mathrm{~F}$ & oropharynx & $3 \%$ & $6 \%$ & $5 \%$ \\
\hline
\end{tabular}

Table 4. $/ \mathrm{s}^{\mathrm{f}} /$ word-initial and -final in three-vocalic contexts

\begin{tabular}{|c|c|c|c|c|c|}
\hline \multicolumn{2}{|c|}{ Emphatics } & \multirow{2}{*}{$\begin{array}{l}\begin{array}{l}\text { Tongue } \\
\text { projection }\end{array} \\
\text { oropharynx }\end{array}$} & \multirow{2}{*}{$\begin{array}{l}\text { Hypoid bone } \\
\text { elevation }\end{array}$} & \multirow{2}{*}{$\begin{array}{c}\begin{array}{c}\text { Larynx } \\
\text { raising }\end{array} \\
10 \%\end{array}$} & \multirow{2}{*}{$\begin{array}{l}\begin{array}{l}\text { Oropharyngeal } \\
\text { narrowing }\end{array} \\
13 \%\end{array}$} \\
\hline$/ s^{\mathrm{f}} \mathrm{u}: \mathrm{b} /$ & M & & & & \\
\hline & $\mathrm{F}$ & oropharynx & $3 \%$ & $6 \%$ & $8 \%$ \\
\hline \multirow[t]{2}{*}{ /si $\dot{i}: b /$} & M & oropharynx & $7 \%$ & $2 \%$ & $11 \%$ \\
\hline & $\mathrm{F}$ & oropharynx & $5 \%$ & $2 \%$ & $5 \%$ \\
\hline \multirow[t]{2}{*}{$/ \mathbf{s}^{\mathfrak{i}} \mathrm{u}: \mathrm{s}^{\mathrm{f}} /$} & M & oropharynx & $7 \%$ & $2 \%$ & $10 \%$ \\
\hline & $\mathrm{F}$ & oropharynx & $9 \%$ & $4 \%$ & $11 \%$ \\
\hline \multirow[t]{2}{*}{ /bas ${ }^{\mathrm{i}} /$} & M & oropharynx & $10 \%$ & $8 \%$ & $10 \%$ \\
\hline & $\mathrm{F}$ & oropharynx & $7 \%$ & $7 \%$ & $9 \%$ \\
\hline \multirow[t]{2}{*}{ /bas ${ }^{\mathrm{i}} \mathrm{i}: \mathrm{s}^{\mathrm{i}}$ / } & $\mathrm{M}$ & oropharynx & $11 \%$ & $10 \%$ & $13 \%$ \\
\hline & $\mathrm{F}$ & oropharynx & $10 \%$ & $8 \%$ & $10 \%$ \\
\hline \multirow[t]{2}{*}{$/ s^{\mathrm{f}} \mathrm{u}: \mathbf{s}^{\mathrm{q}} /$} & M & oropharynx & $3 \%$ & $2 \%$ & $6 \%$ \\
\hline & $\mathrm{F}$ & oropharynx & $2 \%$ & $2 \%$ & $3 \%$ \\
\hline
\end{tabular}

sounds (fig. 2). The tongue approaches its appropriate anterior region in the oral cavity with its root retracted into the oropharynx. As a result, the hyoid bone is elevated and the larynx is raised. Males, in general, narrow the oropharynx, elevate the hyoid bone and raise the larynx more than women (tables 2-5).

\section{Discussion}

This study addresses three main questions: (1) Do Jordanian males and females produce emphatics with pharyngealization, uvularization or velarization? (2) What are the articulatory features accompanying the produc-
Table 3. $/ \mathrm{d}^{\mathrm{f}} /$ word-initial and -final in three-vocalic contexts

\begin{tabular}{|c|c|c|c|c|c|}
\hline \multicolumn{2}{|l|}{ Emphatics } & \multirow{2}{*}{$\begin{array}{l}\begin{array}{l}\text { Tongue } \\
\text { projection }\end{array} \\
\text { oropharynx }\end{array}$} & \multirow{2}{*}{$\begin{array}{l}\begin{array}{l}\text { Hypoid bone } \\
\text { elevation }\end{array} \\
5 \%\end{array}$} & \multirow{2}{*}{$\begin{array}{l}\begin{array}{c}\text { Larynx } \\
\text { raising }\end{array} \\
5 \%\end{array}$} & \multirow{2}{*}{$\begin{array}{l}\begin{array}{l}\text { Oropharyngeal } \\
\text { narrowing }\end{array} \\
13 \%\end{array}$} \\
\hline$/ \mathbf{d}^{\mathrm{i}} \mathrm{ar} /$ & M & & & & \\
\hline & $\mathrm{F}$ & oropharynx & $2 \%$ & $3 \%$ & $6 \%$ \\
\hline \multirow[t]{2}{*}{ /d $\mathbf{d}^{\mathrm{i}} \mathrm{i}: \mathrm{f} /$} & $\mathrm{M}$ & oropharynx & $4 \%$ & $10 \%$ & $10 \%$ \\
\hline & $\mathrm{F}$ & oropharynx & $6 \%$ & $5 \%$ & $4 \%$ \\
\hline \multirow[t]{2}{*}{$/ \mathbf{d}^{\mathrm{f}} \mathrm{u}: \mathrm{d} z /$} & M & oropharynx & $8 \%$ & $5 \%$ & $16 \%$ \\
\hline & $\mathrm{F}$ & oropharynx & $7 \%$ & $2 \%$ & $11 \%$ \\
\hline \multirow[t]{2}{*}{ /bad ${ }^{\Upsilon} /$} & $\mathrm{M}$ & oropharynx & $6 \%$ & $3 \%$ & $16 \%$ \\
\hline & $\mathrm{F}$ & oropharynx & $3 \%$ & $2 \%$ & $10 \%$ \\
\hline \multirow[t]{2}{*}{ /bi: $\mathbf{d}^{\mathrm{f}}$} & M & oropharynx & $2 \%$ & $3 \%$ & $14 \%$ \\
\hline & $\mathrm{F}$ & oropharynx & $3 \%$ & $1 \%$ & $6 \%$ \\
\hline \multirow[t]{2}{*}{ /furu:d ${ }^{\mathrm{f}}$ / } & M & oropharynx & $3 \%$ & $3 \%$ & $8 \%$ \\
\hline & $\mathrm{F}$ & oropharynx & $5 \%$ & $4 \%$ & $9 \%$ \\
\hline
\end{tabular}

Table 5. $/ ð^{\Upsilon} /$ word-initial and -final in three-vocalic contexts

\begin{tabular}{|c|c|c|c|c|c|}
\hline \multicolumn{2}{|l|}{ Emphatics } & \multirow{2}{*}{$\begin{array}{l}\begin{array}{l}\text { Tongue } \\
\text { projection }\end{array} \\
\text { oropharynx }\end{array}$} & \multirow{2}{*}{$\begin{array}{l}\text { Hypoid bone } \\
\text { elevation }\end{array}$} & \multirow{2}{*}{$\begin{array}{l}\text { Larynx } \\
\text { raising }\end{array}$} & \multirow{2}{*}{$\begin{array}{l}\begin{array}{l}\text { Oropharyngeal } \\
\text { narrowing }\end{array} \\
6 \%\end{array}$} \\
\hline /ðீar/ & M & & & & \\
\hline & $\mathrm{F}$ & oropharynx & $3 \%$ & $3 \%$ & $3 \%$ \\
\hline \multirow[t]{2}{*}{ /ठำ } & M & oropharynx & $2 \%$ & $3 \%$ & $6 \%$ \\
\hline & $\mathrm{F}$ & oropharynx & $1 \%$ & $2 \%$ & $5 \%$ \\
\hline \multirow[t]{2}{*}{ /ठ $\mathbf{d}^{\mathrm{u}} \mathrm{u}: \mathrm{d} z /$} & M & oropharynx & $3 \%$ & $1 \%$ & $6 \%$ \\
\hline & $\mathrm{F}$ & oropharynx & $6 \%$ & $3 \%$ & $11 \%$ \\
\hline \multirow[t]{2}{*}{ /bað'/ } & M & oropharynx & $9 \%$ & $2 \%$ & $11 \%$ \\
\hline & $\mathrm{F}$ & oropharynx & $7 \%$ & $2 \%$ & $5 \%$ \\
\hline \multirow[t]{2}{*}{ /bì: $\mathbf{d}^{\mathrm{f}} /$} & M & oropharynx & $7 \%$ & $1 \%$ & $8 \%$ \\
\hline & $\mathrm{F}$ & oropharynx & $7 \%$ & $3 \%$ & $3 \%$ \\
\hline \multirow[t]{2}{*}{ /furt: $\mathbf{d}^{\mathrm{f} /}$} & $\mathrm{M}$ & oropharynx & $4 \%$ & $1 \%$ & $3 \%$ \\
\hline & $\mathrm{F}$ & oropharynx & $3 \%$ & $1 \%$ & $3 \%$ \\
\hline
\end{tabular}

tion of the emphatic consonants? (3) Does the hyoid bone elevate and larynx raise as a result of tongue retraction?

As for the first question, it has been found that Jordanian male and female speakers produce emphatics with pharyngealization. We keep a clear distinction between the voiceless and voiced pharyngeal fricatives $/ \mathrm{h}^{\mathrm{f}} /$ and $/ \mathrm{f} /$, which have primary articulation in the laryngopharynx, and pharyngealized consonants that have two simultaneous articulations, where the pharyngeal articulation, according to Catford [20], is considered the secondary one with less constriction than the primary articulation [21]. The secondary constriction for the $/ \mathrm{t}^{\mathrm{f}}, \mathrm{d}^{\mathrm{q}}, \mathrm{s}^{\mathrm{q}}, \mathrm{\partial}^{\mathrm{q}} /$ emphatics is in the oropharynx with an average 11 and 7\% narrowing for males and females, respectively. This narrow- 


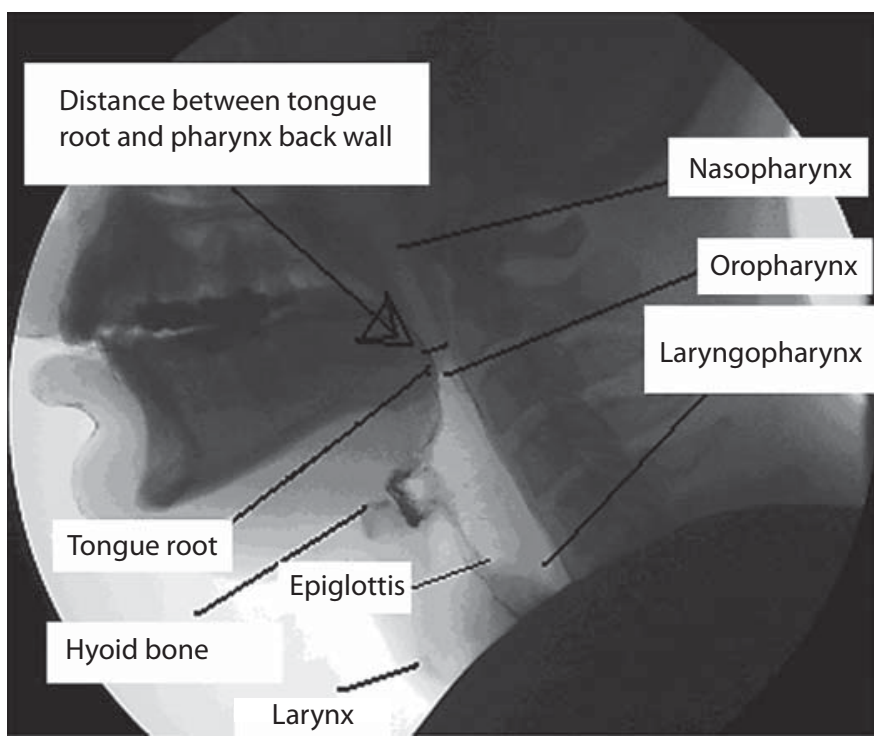

Fig. 3. Larynx, laryngopharynx, oropharynx, nasopharynx, hyoid bone, larynx, epiglottis and tongue root in a male speaker.

ing is located at the level of the second vertebra. No role for the velum or uvula has been noticed. Current findings are in contrast with findings of other studies that relate emphasis to velarization or uvularization.

Zawaydeh's $[12,13]$ nasoendoscopic population is herself as a native speaker of Jordanian Arabic. However, positioning the fiber-optic 1 inch below the uvula raises a question on how it was possible for the author to see the uvular gesture for the emphatics. Results of other studies that show the emphatics as uvularized or velarized in other dialects could be attributed to the fact that emphasis is realized differently [22].

In their acoustic and auditory analysis of $/ \mathrm{t}, \mathrm{t}^{\mathrm{i}} /$ in Jordanian male and female speakers, Khattab et al. [23] find that the constriction made for the production of this emphatic sound is in the upper two thirds of the pharynx. The raising of the first formant and the lowering of the second formant indicate a constriction in the postuvular

of the tongue into the oropharynx is associated with hyoid bone elevation and upward movement of the larynx. The percentage of males' hyoid movement and larynx raising is higher than that of the females.

The elevation of the hyoid bone is done by the suprahyoid extrinsic muscles. 'The hyoid bone may consequently raise the larynx, given the absence of opposition by the infrahyoid muscles' $[25, \mathrm{p}$. 128]. The overall larynx elevation is almost the same for the two sexes. The pharyngeal narrowing happens due to the tongue root retraction in the oropharyngeal region. The average narrowing percentage of the oropharynx for males is $11 \%$ and for females $6.5 \%$. What seems to prove that hyoid bone elevation and larynx raising are the result of tongue root retraction is the fact that the more the tongue retracts the higher the hyoid bone elevates and the larynx raises. This is clear across gender where males retract the tongue more than females. This finding goes in line with the speculations of Giannini and Pettorino [9].

\section{Conclusion}

The main articulatory features accompanying the production of emphatic consonants have been identified across Jordanian male and female speakers. Videofluoroscopic images show that emphatics are produced as pharyngealized sounds. They start with the tongue root retracting into the oropharynx and the hyoid bone elevating and the larynx raising as a result. Further studies are needed to examine at what age children master emphatics in Jordanian Arabic. Future research might also include electromyographic analysis to trace the sequence of muscle activities in the production of emphatic consonants and explain how tongue root retraction elevates the hyoid bone and then raises the larynx. pharyngeal region.

The other articulatory configurations accompanying the oropharyngeal narrowing are the elevation of the hyoid bone and the raising of the larynx (fig. 3). The role of the hyoid bone or the larynx has been controversial in the pharyngealized consonants. In the current study, the hyoid bone is involved in the articulation of pharyngealized consonants. Males have much farther elevation than females due to physiological factors [24]. Since the hyoid bone supports the tongue root, the downward retraction

References
1 Trubetzkoy N: Anleitung zur phonologischen Beschreibung. Prague, Edition du Cercle Linguistique de Prague, 1935.

2 Gairdner W: Phonetics of Arabic. London, Oxford University Press, 1925.

3 O'Connor J: Phonetics. Harmondsworth, Penguin, 1973.

4 Jakobson R: Muffxama, the 'emphatic' phonemes in Arabic; in Pulgram E (ed): Studies Presented to Joshua Whatmough on his 60th Birthday. The Hague, Mouton, 1957, pp 105115.

5 Al-Ani S: Arabic Phonology. The Hague, Mouton, 1970. 
6 Delattre P: Pharyngeal features in the consonants of Arabic, German, Spanish, French, and American English. Phonetica 1971;23: 129-155.

7 Laufer A, Baer T: The emphatic and pharyngeal sounds in Hebrew and Arabic. Lang Speech 1988;31:181-205.

8 Ali L, Daniloff R: A cinefluorographic-phonological investigation of emphatic sound assimilation in Arabic. 17th Int Congr Phonet Sci 1972, pp 638-648.

9 Giannini A, Pettorino M: The emphatic consonants in Arabic. Speech Laboratory Report. Naples, Instituto Universitario Orientale, 1982.

10 Khan M: Arabic emphatics: the evidence for cultural determinants of phonetic sex-typing. Phonetica 1975;31:38-50.

11 Davis S: Emphasis spread in Arabic and grounded phonology. Ling Inquiry 1995;26: 465-498.

12 Zawaydeh B: Gradient uvularization spread in Ammani-Jordanian Arabic; in Eid M, Benmamoun E (eds): Perspectives on Arabic Linguistics. Amsterdam, Benjamins, 1998, pp 117-141.

13 Zawaydeh B: The Phonetics and Phonology of Gutturals in Arabic; PhD thesis Indiana University, 1999.
14 Lehn W: Emphasis in Cairo Arabic. Language 1963;39:29-39.

15 Odisho E: The role of the rear section of the vocal tract in Baghdadi Arabic; MPhil thesis University of Leeds, 1973.

16 Panconcelli-Calzia G: Experimentalphonetische Untersuchungen. Z Eingeborenensprachen 1924;182-188.

17 Marçais P: L'articulation de l'emphase dans un parler arabe magrébien. Ann l'Inst d'Etudes Orientales 1948;7:5-28.

18 Blanc H: Studies in Northern Palestinian Arabic. Jerusalem, Israel Oriental Society, 1953.

19 Al-Tamimi F: Phonetic and Phonological Variation in the Speech of Rural Migrants in a Jordanian City; PhD thesis University of Leeds, 2001.

20 Catford J: Fundamental Problems in Phonetics. Edinburgh, Edinburgh University Press, 1977.

21 Laufer A: Phonetic Transcription. Jerusalem, Academon, 1985.

22 Norlin K: A phonetic study of emphasis and vowels in Egyptian Arabic. Lund University, Department of Linguistics Working Papers, 1987.
23 Khattab G, Al-Tamimi F, Heselwood B: Acoustic and auditory differences in the /t/$/ \mathrm{t}^{\mathrm{f}} /$ opposition in male and female speakers of Jordanian Arabic; in Boudela S (ed): Perspectives on Arabic Linguistics. Amsterdam, Benjamins, 2006, pp 131-160.

$>24$ Kendall K, Leonard R: Hyoid movement during swallowing in older patients with dysphagia. Arch Otolayngol Head Neck Surg 2001;127:1224-1229.

-25 Burnett T, Mann E, Cornell S, Ludlow C: Laryngeal elevation achieved by neuromuscular stimulation at rest. J Appl Physiol 2003; 94:128-134.

26 Wallin GA: Über die Laute des Arabischen und ihre Bezeichnung. Z Dtsch Morgenländ Ges 1855-58;9:1-69.

27 Brücke E: Beiträge zur Lautlehre der arabischen Sprachen. Wien Sitzungsber Phil Histor Classe 1860;307-356.

28 Haupt P: Über die semitischen Sprachlaute und ihre Umschrift. Beitr Assyriol 1890: 249-267.

29 Panconcelli-Calzia G: Experimentalphonetische Untersuchungen. Z Eingeborenensprachen 1924;182-188.

30 Royal AM: Male/Female Pharyngealization Patterns in Cairo Arabic: A Sociolinguistic Study of Two Neighborhoods; PhD thesis University of Texas at Austin, 1985. 